\title{
Permanence of Lung Disorders after Hospital Discharge of Patients Who Underwent Cardiac Surgery: An Integrative Review
}

\author{
Daniela Di Bernardi', Marcos Bagrichevsky²* ${ }^{\circledR}$, Christiani Decker Batista Bonin ${ }^{1}$ \\ ${ }^{1}$ Instituto de Ensino Superior (IES), Florianópolis, Brasil \\ ${ }^{2}$ Departmento de Medicina, Universidade Regional de Blumenau (FURB), Blumenau, Brasil \\ Email: *marcos_bagrichevsky@yahoo.com.br
}

How to cite this paper: Di Bernardi, D., Bagrichevsky, M. and Bonin, C.D.B. (2020) Permanence of Lung Disorders after Hospital Discharge of Patients Who Underwent Cardiac Surgery: An Integrative Review. Health, 12, 194-203.

https://doi.org/10.4236/health.2020.122016

Received: January 25, 2020

Accepted: February 16, 2020

Published: February 19, 2020

Copyright $\odot 2020$ by author(s) and Scientific Research Publishing Inc. This work is licensed under the Creative Commons Attribution International License (CC BY 4.0).

http://creativecommons.org/licenses/by/4.0/ (c) (i) Open Access

\begin{abstract}
Patients are more likely to develop lung disorders after cardiac surgery. Pulmonary dysfunction resulting from cardiac surgery in the hospital phase is well documented. However, there is a scarcity of studies related to the permanence of pulmonary disorders in the period following hospital discharge. The objective of this study was to verify in a database investigation the permanence of pulmonary dysfunctions after hospital discharge of patients who underwent cardiac surgery. A literature review with an integrative approach was carried out in the National Library of Medicine (Pubmed) and Scientific Electronic Library Online (Scielo) databases from 1978 to 2019. 4523 articles were found and after applying the inclusion and exclusion criteria, the sample was composed of 14 articles relevant to the subject and that were available in full. The results demonstrated the presence of atelectasis, pleural effusion, diaphragmatic dysfunction, respiratory symptoms such as cough, phlegm, wheezing, and dyspnea, reduced static and dynamic lung volumes, reduced diffusion capacity and respiratory muscle strength, in the period that ranged from three weeks to one year after cardiac surgery. Further studies are needed to elucidate the mechanisms that lead to the permanence of pulmonary dysfunctions after hospital discharge in patients who underwent cardiac surgery.
\end{abstract}

\section{Keywords}

Thoracic Surgery, Cardiac Surgery, Pulmonary Function Test, Respiratory Function Tests

\section{Introduction}

Cardiovascular diseases (CVDs) are among the main causes of death in devel- 
oped countries and they remain the leading cause of illness and professional disability [1] [2], due to increased longevity, urbanization, and lifestyle habits [3]. In Brazil, they also represent the first cause of mortality and the second largest cause of hospitalization [4] [5], with important consequences such as physical disability and invalidity, which contribute to the increase in health expenses [6] [7].

Among the forms of treatment for CVDs, cardiac surgery (CS) stands out, including myocardial revascularization, valve repairs and exchanges, and the correction of congenital heart diseases as the main procedures [8]. CS and postoperative control (PO) have added, in the last decades, greater knowledge and scientific experience, with high-tech equipment and state-of-the-art drugs, making procedures faster, less invasive, and less harmful to cardiac patients. Minimally invasive interventions, without cardiopulmonary bypass (CPB) and with less surgical time are examples of this technological advance [9]. Although it is an effective procedure and it has evolved over the years, its endpoint may have cardiac, pulmonary, renal, neurological, infectious, hematological, digestive, and electrolyte complications [10] [11].

Within the set of postoperative complications related to CS, several studies report that pulmonary dysfunction is prevalent [5] [8] [11] [12] [13] [14] [15] and its etiology may result from the association of multiple surgical risk factors [3] [11] [14]. The pre-surgical risk factors listed are age, smoking, previous medical history, and preoperative pulmonary function [11]. Among the intraand post-surgical risk factors are anesthesia, $\mathrm{CPB}$ time, cardiac arrest, surgical trauma, median sternotomy, pleurotomy, phrenic nerve palsy, time on mechanical ventilation, number and position of chest drains, and post-operative pain [3] [14].

Most patients undergoing CS develop postoperative pulmonary dysfunction with significant reduction in lung volumes, impaired respiratory mechanics, decreased lung compliance, and increased work of breathing [14]. The reduction in lung volumes and capacities contributes to changes in gas exchange, resulting in hypoxemia and decreased diffusion capacity [13] [14]. Atelectasis, pleural effusion, and pneumonia are pulmonary complications frequently found [12] [16] [17]. However, other complications such as hypercapnia, reintubation, and respiratory failure are also observed [14]. These pulmonary dysfunctions and complications are responsible for prolonging hospital stay, increasing hospital costs, and an important cause of morbidity and mortality in patients undergoing CS [11].

Studies related to pulmonary dysfunctions in the postoperative period of CS until hospital discharge are well established in the literature [5] [8] [11] [13] [16]. Nonetheless, few studies report the permanence of the deleterious effects on lung function resulting from CS after hospital discharge [18] [19] [20] [21] [22]. According to Belle et al. [23] and Johnson et al. [24], little is known about the outcome of abnormalities in lung function in the weeks following hospital discharge. Westerdahl et al. [22] stated that the reduction in lung function and 
pain caused by median sternotomy are common and well documented until hospital discharge. However, few studies have assessed the deleterious effects of CS on long-term lung function.

In this context, the objective of the study was to verify in the databases the presence of investigations that show the permanence of pulmonary dysfunctions after hospital discharge of patients undergoing CS.

\section{Methods}

This study was characterized as a literature review with an integrative approach, which selected articles through the databases National Library of Medicine (Pubmed) and Scientific Electronic Library Online (Scielo). The search was carried out in March 2019, using the Health Sciences Descriptors (DeCS) in Portuguese: "cirurgia torácica", "cirurgia cardíaca", "teste de função pulmonar", "teste de função respiratória”; and in English: "thoracic surgery", "cardiac surgery", "respiratory function test", "pulmonary function test".

As an inclusion criterion, articles published between January 1978 and March 2019, published in Portuguese and English, which presented abstracts available online and digital access in full, were selected. Articles that did not meet the inclusion criteria and were found to be repeated and/or duplicated in the databases were excluded.

The studies were selected first by reading the titles for each database, following the eligibility criteria. After this selection, the study abstracts were read and then the articles that were available in full were analyzed. Those that did not correspond to the basic question of the study and that did not meet the inclusion criteria were excluded (Figure 1).

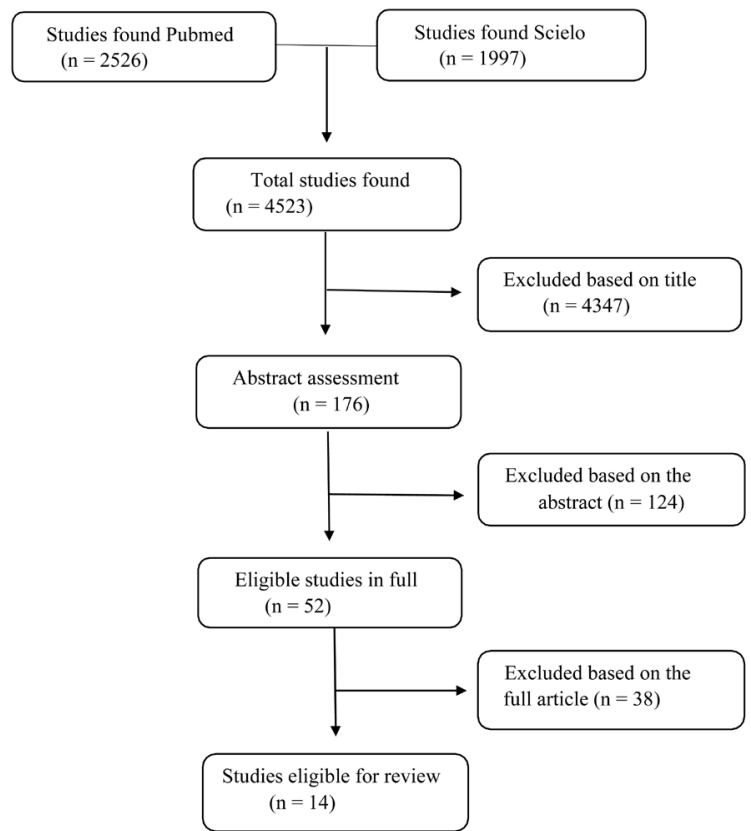

Figure 1. Flowchart for the selection of studies. Source: Prepared by the authors; n: number of articles. 
The main characteristics of the articles included in this review are described in Table 1 . The analyzed data were distributed in columns, with the following description: author/journal/year of publication, title, objective, method, and endpoint.

\section{Results and Discussion}

The results found demonstrated the persistence of pulmonary dysfunctions in patients who underwent MRS and/or valve reconstruction surgery, in a period of time that varied from three weeks to one year of PO, showing that the impairment of lung function may continue beyond hospital discharge. Some authors have demonstrated long-term changes in lung function through the analysis of static and dynamic volumes [18] [19] [20] [21] [22] [23] [25] [26] and the diffusing capacity of the lungs for carbon monoxide (DLCO) [18] [22]. Other investigators reported the persistence of pulmonary dysfunctions through the observation of diaphragmatic disorders [27] [28] [29] [30]. In turn, Landymore et al. [31] associated the presence of pulmonary dysfunctions with the types of grafts used in CS and Johnson et al. [24] correlated the dysfunctions with respiratory symptoms such as cough, discharge, wheezing, and dyspnea.

Westherdal et al. [22] and Braun et al. [18] demonstrated a decrease in static and dynamic volumes and DLCO, in relation to preoperative values after four months and one hundred and sixteen days of MRS, respectively. Shapira et al. [20] also found significant reductions in the values of static and dynamic volumes after three months of MRS. Similarly, Van Belle et al. [23] and Berriztbeitia et al. [19] showed a decrease in the values of static and dynamic volumes after six weeks and six to eight weeks of MRS, respectively. Shenkman et al. [21] noticed a greater decrease in both lung volumes after three weeks of MRS or valve surgery. Following three months of surgical intervention, Shenkman et al. [21] reported an increase in the studied variables without reaching preoperative values.

Rachwalic [25] and Vaydia et al. [26] observed persistent pulmonary dysfunction through the analysis of static and dynamic lung volumes in patients who underwent valve surgery and both reported a decrease in lung volumes. Two and a half months after valve surgery, Rachwalic [25] indicated that there was a $20 \%$ reduction in static and dynamic volumes and, in six months, they found that these values remained 5\% below preoperative levels. Vaydia et al. [26] corroborated these findings when they concluded that 17 of the 31 patients in their study had reduced spirometric values three months after the surgical intervention

Other investigations have shown pulmonary dysfunction through the analysis of diaphragmatic disorders [27] [28] [29] [30]. Baltieri et al. [27], in a case report of a patient undergoing MRS, demonstrated partial resolution of diaphragmatic dysfunction after 10 weeks of transcutaneous electrical diaphragmatic stimulation. Dimopoulou et al. [28] studied 63 patients who underwent two different cardiac cooling techniques (saline and "ice-slush") during CS and they concluded that after 30 days, eight out of 10 patients still had reduced latency time 
Table 1. Results of studies on the permanence of pulmonary dysfunctions after hospital discharge of patients who underwent cardiac surgery.

\begin{tabular}{|c|c|c|c|c|}
\hline Author/Journal/Year & Title & Objetive & Method & Outcome \\
\hline $\begin{array}{l}\text { Baltieri et al. } \text { [27] } \\
\text { Revista Brasileira de } \\
\text { Cardiologia, } 2012\end{array}$ & $\begin{array}{l}\text { Transcutaneous } \\
\text { electrical } \\
\text { diaphragmatic } \\
\text { stimulation in } \\
\text { diaphragmatic } \\
\text { paralysis } \\
\text { after cardiac surgery }\end{array}$ & $\begin{array}{l}\text { Observe the } \\
\text { influence } \\
\text { of TEDS on } \\
\text { diaphragmatic } \\
\text { paralysis after MRS }\end{array}$ & $\begin{array}{l}\mathrm{n}=1 \\
\text { Submitted to MRS } \\
\text { Pre-operatively assessed by } \\
\text { X-ray, } 30 \text { physical therapy } \\
\text { sessions without TEDS and } \\
\text { another } 20 \text { physical therapy } \\
\text { sessions with TEDS } \\
\text { (total = } 50 \text { sessions } \\
\text { or } 10 \text { weeks) } \\
\text { of physical therapy } \\
\text { in the PO of MRS }\end{array}$ & $\begin{array}{l}30 \text { sessions without } \\
\text { TEDS = there was no } \\
\text { symptomatic improvement } \\
\text { of diaphragmatic } \\
\text { dysfunction and the } \\
\text { previous image remained } \\
\text { on the chest X-ray } \\
20 \text { additional sessions } \\
\text { (10 weeks) with TEDS = } \\
\text { partial resolution of } \\
\text { diaphragmatic paralysis } \\
\text { was observed }\end{array}$ \\
\hline $\begin{array}{c}\text { Rachwalik [25] } \\
\text { Clinical and } \\
\text { Experimental } \\
\text { Medicine Letters, } 2008\end{array}$ & $\begin{array}{l}\text { Spirometric changes } \\
\text { after valve surgery }\end{array}$ & $\begin{array}{l}\text { Elucidate the degree } \\
\text { of recovery of } \\
\text { spirometric values } \\
\text { after } 6 \text { months } \\
\text { of open CS }\end{array}$ & $\begin{array}{l}\mathrm{n}=26 \\
\text { Those who underwent } \\
\text { valve surgery } \\
\text { Preoperatively assessed, } \\
5 \text { days, } 2.5 \text { months, } \\
\text { and } 6 \text { months of PO }\end{array}$ & $\begin{array}{l}2.5 \text { months }=20 \% \text { reduction } \\
\text { in TV, FEV1, FEF } 25 \% \text {, } \\
\text { FEF50\% FEF75\% } \\
6 \text { months = all variables } \\
\text { persisted } 5 \% \text { below } \\
\text { preoperative values }\end{array}$ \\
\hline $\begin{array}{c}\text { Westerdahl et al. [22] } \\
\text { Respiratory } \\
\text { Medicine, } 2003\end{array}$ & $\begin{array}{l}\text { Pulmonary function } 4 \\
\text { months after coronary } \\
\text { artery bypass } \\
\text { graft surgery }\end{array}$ & $\begin{array}{l}\text { Describe lung } \\
\text { function and pain } 4 \\
\text { months after MRS }\end{array}$ & $\begin{array}{l}\mathrm{n}=25 \\
\text { Those who underwent MRS } \\
\text { Preoperatively assessed, } 4 \\
\text { days and } 4 \text { months of PO }\end{array}$ & $\begin{array}{l}4 \text { months = TV, IC, FEV } 1 \text {, } \\
\text { FRC, TPC, DLCO, PEF were } \\
\text { reduced from } 6 \text { to } 13 \% \text { in } \\
\text { relation to preoperative values }\end{array}$ \\
\hline $\begin{array}{c}\text { Berrizbeitia et al. [19] } \\
\text { Chest, } 1998\end{array}$ & $\begin{array}{l}\text { Effects of sternotomy } \\
\text { and coronary bypass } \\
\text { surgery on } \\
\text { postoperative } \\
\text { pulmonary mechanics }\end{array}$ & $\begin{array}{l}\text { To determine the } \\
\text { effect of median } \\
\text { sternotomy and } \\
\text { types of grafts on } \\
\text { lung function } \\
\text { in the PO of MRS }\end{array}$ & $\begin{array}{l}\mathrm{n}=55 \\
\text { Those who underwent MRS } \\
\text { Preoperatively assessed } \\
\text { and } 6 \text { to } 8 \text { weeks of PO }\end{array}$ & $\begin{array}{l}6 \text { to } 8 \text { weeks = reduction in } \\
\text { FVC, } \% \text { FVC, FEF } 25 \%-75 \% \text {, } \\
\% \text { FEF } 25 \%-75 \% \text {, more } \\
\text { evident in patients } \\
\text { who used IMA as a graft }\end{array}$ \\
\hline $\begin{array}{c}\text { Dimopoulou et al. [28] } \\
\text { Chest, } 1998\end{array}$ & $\begin{array}{l}\text { Phrenic nerve } \\
\text { dysfunction after } \\
\text { cardiac operations }\end{array}$ & $\begin{array}{l}\text { Electrophysiologically } \\
\text { determine risk factors } \\
\text { for the development } \\
\text { of phrenic nerve } \\
\text { dysfunction after CS }\end{array}$ & $\begin{array}{l}\mathrm{n}=63 \\
\text { Those who underwent } \\
\text { MRS and valve surgery } \\
\text { Preoperatively assessed, } \\
24 \text { hours, } 7 \text { days, and } \\
30 \text { days of PO }\end{array}$ & $\begin{array}{l}30 \text { days }=8 \text { out of } 10 \text { patients } \\
\text { still had a reduction in the } \\
\text { latency time of phrenic } \\
\text { nerve conduction }\end{array}$ \\
\hline $\begin{array}{l}\text { Shenkman et al. }[21] \\
\text { Acta Anaesthesiologica } \\
\text { Scandinavica, } 1997\end{array}$ & $\begin{array}{l}\text { The effects of } \\
\text { cardiac surgery on } \\
\text { early and late } \\
\text { pulmonary function }\end{array}$ & $\begin{array}{l}\text { Assess the immediate } \\
\text { and late effects of CS } \\
\text { on pulmonary } \\
\text { function tests }\end{array}$ & $\begin{array}{l}\mathrm{n}=50 \\
\text { Those who underwent } \\
\text { MRS or valve surgery } \\
\text { Preoperative assessment, } \\
3 \text { weeks and } 3.5 \text { months of } \\
\text { PO }\end{array}$ & $\begin{array}{l}3 \text { weeks = greater reduction } \\
\text { in FEV1, FEF } 50 \%, \text { FEF } 75 \% \text {, } \\
\text { FVC, MVV, and PEF } \\
3 \text { months = increased } \\
\text { variables but they did not } \\
\text { reach preoperative values }\end{array}$ \\
\hline $\begin{array}{c}\text { Johnson et al. [24] } \\
\text { Journal of Cardiothoracic } \\
\text { and Vascular } \\
\text { Anaesthesia, } 1996\end{array}$ & $\begin{array}{l}\text { Respiratory function } \\
\text { after cardiac surgery }\end{array}$ & $\begin{array}{l}\text { Relating pulmonary } \\
\text { dysfunction to the } \\
\text { presence of } \\
\text { respiratory } \\
\text { symptoms in patients } \\
\text { who underwent CS }\end{array}$ & $\begin{array}{l}\mathrm{n}=138 \\
\text { Those who underwent } \\
\text { MRS or valve surgery } \\
\text { Assessed on admission } \\
\text { and } 8 \text { weeks of PO }\end{array}$ & $\begin{array}{l}8 \text { weeks = respiratory } \\
\text { symptoms (cough, discharge, } \\
\text { wheezing, and dyspnoea) are } \\
\text { correlated with the presence } \\
\text { of atelectasis and with reduced } \\
\text { respiratory muscle strength, } \\
\text { and spirometric values }\end{array}$ \\
\hline $\begin{array}{l}\text { Vaidya et al. [26] } \\
\text { The Journal of } \\
\text { Cardiovascular } \\
\text { Surgery, } 1996\end{array}$ & $\begin{array}{l}\text { Spirometric changes } \\
\text { after open mitral } \\
\text { surgery }\end{array}$ & $\begin{array}{l}\text { Assess spirometric } \\
\text { values after valve } \\
\text { reconstruction } \\
\text { surgery }\end{array}$ & $\begin{array}{l}\mathrm{n}=31 \\
\text { Those who underwent } \\
\text { valve reconstruction surgery } \\
\text { Preoperative assessment } \\
\text { and } 3 \text { months of PO }\end{array}$ & $\begin{array}{l}3 \text { months }=17 \text { out of } 31 \\
\text { patients had } \\
\text { low-value spirometry }\end{array}$ \\
\hline
\end{tabular}




\section{Continued}

Van Belle et al. [23]

Respiratory

Medicine, 1992

Efthimiou et al. [29]

Annals Thoracic

Surgery, 1991

\section{Landymore et al. [31] \\ European Journal of \\ Cardio-thoracic \\ Surgery, 1990}

Shapira et al. [20]

Annals Thoracic Surgery, 1990

\section{Curtis et al. [30] \\ The Annals of} Thoracic Surgery, 1989

Braun et al. [18]

Chest, 1978
Postoperative pulmonary functions abnormalities after coronary artery by-pass surgery

Diaphragm paralysis following cardiac surgery: role of phrenic nerve cold injury

\section{Pulmonary}

complications

following myocardial

revascularization

with de internal

mammary artery graft
Determinants of pulmonary functions in patients undergoing coronary bypass operations

\section{Elevated hemidiaph-} ragm after cardiac operations: incidence, prognosis, and relationship to the use of topical ice slush

Pre and postoperative pulmonary function abnormalities in coronary artery revascularization surgery
Assess the effects

of MRS on lung

function after

1 and 6 weeks of $\mathrm{PO}$

Compare the

frequency and diaphragmatic paralysis in patients who underwent CS with or without "ice/slush"* natural history of
Determine the incidence and etiology of pulmonary complications after MRS with IMA graft $\mathrm{n}=34$

Those who underwent MRS Preoperatively assessed, 1 week and 6 weeks of $\mathrm{PO}$

$\mathrm{n}=100$

Those who underwent MRS

Group I ( $\mathrm{n}=50)$-with

"ice-slush"*,

Group II $(\mathrm{n}=50)$-without

"ice-slush"*

Assessed by X-ray,

1 week, 1 month,

and every 6 months of PO

$\mathrm{n}=106$

Those who underwent

MRS and valve surgery

Group I (control) -

saphenous graft,

Group II-IMA

with pleural dissection

Group III-IMA

without pleural dissection

Assessed with

3 months of PO, by X-ray

Determine the immediate and late effect of median sternotomy on lung function

Determine the incidence and prognosis of elevated hemidiaphragm in patients who underwent CS with "ice/slush"*

$\mathrm{n}=29$

Those who underwent MRS

Preoperatively assessed, at hospital discharge, and 3 months of PO

\section{$\mathrm{n}=745$}

Those who underwent MRS with "ice-slush"* Preoperatively assessed, 1 month, and 1 year of $\mathrm{PO}$

Assess the
preoperative
pulmonary status
and late PO of
patients who
underwent MRS

\author{
$\mathrm{n}=19$ \\ Those who underwent MRS \\ Preoperatively assessed, \\ 1 to 2 days, 2 weeks \\ and mean 116 days of PO
}

6 weeks $=$ significant persistence of reduction in TPC, FEV1, and $\mathrm{TV}$ in relation to preoperative values

1 month $=12$ patients in Group I had diaphragmatic paralysis 1 year $=5$ patients in Group I had diaphragmatic paralysis

3 months $=53 \%$ of Group II patients had persistent loss of left lung volume related to atelectasis and left pleural effusion
3 months $=$ some minor reductions were found for IC, TPC, FEV1, FEF 25\% - 75\%, PEF, FVC, and SVC

1 month $=79$ out of 99 patients $(79.8 \%)$ had diaphragmatic elevation 1 year $=14$ out of 64 patients (21.9\%) had diaphragmatic elevation
116 days $=$ reduced VC, TPC, IC, FRC and diffusion capacity

TEDS—-transcutaneous electrical diaphragmatic stimulation; CS—cardiac surgery; $\mathrm{n}$-sample; MRS-myocardial revascularization surgery; X-ray-X-ray; PO-postoperative; TV - tidal volume; FEV1 -forced expired volume in the 1st second; FEF 25\%-forced expiratory flow 25\%; FEF 50\% -forced expiratory flow 50\%; FEF 75\%-forced expiratory flow 75\%; IC-inspiratory capacity; FRC-functional residual capacity; TPC-total pulmonary capacity; DLCO-diffusing capacity of the lungs for carbon monoxide; MEF-peak of maximum expiratory flow; PO_-postoperative; FVC-forced vital capacity; \% FVC-percentage of forced vital capacity; FEF 25\% - 75\%-forced expiratory flow 25\% - 75\%; \% FEF 25\% - 75\% - percentage of forced expiratory flow 25\% - 75\%; IMA-internal mammary artery; MVV—-maximum voluntary ventilation; VC-vital capacity; IMA—internal mammary artery; SVC-slow vital capacity. ${ }^{*}$ ice-slush—-topical myocardial cooling technique used during cardiac surgery. 
of phrenic nerve conduction. Efthimiou et al. [29] verified 100 patients, divided into two groups: 50 individuals in Group I, with "ice-slush" and 50 in Group II, without "ice-slush". After one month and one year of PO of CS, 12 and 5 patients in Group I, respectively, had diaphragmatic paralysis. In turn, Curtis et al. [30] observed diaphragmatic elevation in 79 patients in the first month and in 14 patients after one year; in both situations, patients were submitted to CS with "ice-slush".

Landymore et al. [31] related pulmonary dysfunction to the type of graft used in CS, dividing 106 patients into three groups: Group I (control)-saphenous graft; Group II-internal mammary artery graft (IMA) with dissection of the pleura; and Group III-IMA graft without dissection of the pleura. The authors concluded that $53 \%$ of Group II patients had loss of left lung volume related to atelectasis and left pleural effusion after three months of CS. When analyzing the work by Johnson et al. [24] conducted with 138 patients who underwent MRS and valve surgery, it was possible to notice the presence of atelectasis and reduced respiratory muscle strength correlated with the presence of cough, discharge, wheezing, and dyspnea, after eight weeks of PO.

As for the observation time of pulmonary dysfunctions after CS, a large variation was found between the researchers analyzed. Most investigations have verified these endpoints over a period of three weeks to four months [18]-[28] [31] and only two studies have extended the follow-up time of patients by up to one year [29] [30]. Due to the heterogeneity of the methodological design of the studies in relation to the observation time of the endpoints, it was not possible to establish a comparative analysis to determine which type of pulmonary dysfunction could have persisted longer in the PO of CS.

Regarding the period of publication of the articles, nine selected works (64, $3 \%)$ are from the 1990s, with the most recently published article referring to 2012. No data were found in the researched literature that allowed to explain the reason for the accumulation of investigations in the 1990s and the lack of studies on the subject in the last fifteen years.

With regard to the quantity and origin of publications, this study revealed that almost all of the selected articles (92.8\%) were produced internationally. Only one case report [27] was found, written in Portuguese, a fact that suggests that there is a shortage of similar publications in Brazil and/or in Portuguese that deal with the permanence of pulmonary dysfunctions after hospital discharge in patients who underwent CS.

This study found that patients who underwent CS develop reduced pulmonary function and that these events may persist beyond hospital discharge. Therefore, it is necessary to assess the importance of continuing respiratory physical therapy protocols started in the hospital phase. Westerdahl et al. [22] claim that no method of postoperative therapy has been used to prevent and treat changes in lung function in the long term, and it is also unclear how long after CS breathing exercises should be recommended. Likewise, Forshag and Cooper [32] suggest that an acceptable endpoint for breathing exercises will be 
when the patient's lung function returns to preoperative levels or to a stable baseline.

\section{Conclusion}

The study concluded that pulmonary disorders remained beyond hospital discharge in patients who underwent CS. Such dysfunctions were observed in all selected studies and their duration varied from three weeks to one year of PO of CS. There seems to be a lack of research on the late effects of CS on lung function; there, more studies are needed to elucidate the mechanisms that lead to persistent changes in lung function after discharge from patients who underwent CS.

\section{Collaborators' Participation}

The authors developed and organized all parts of the text in conjunction.

\section{Conflicts of Interest}

The authors of this work declare that there are no conflicts of interest.

\section{References}

[1] Garcia-Rubira, J.C. (2017) Editor Note: Cardiovascular Disease and Diagnosis. Journal of Cardiovascular Diseases \& Diagnosis, 5, e115. https://doi.org/10.4172/2329-9517.1000e115

[2] Ribeiro, K.R.A. (2018) Pós-operatório de revascularização do miocárdio: Complicações e implicações para enfermagem. Journal of Research Online, 10, 254-259. https://doi.org/10.9789/2175-5361.2018.v10i1.254-259

[3] Lima, P.M.B., Cavalcante, H.E.F., Rocha, A.R.M. and Brito, R.T.F. (2011) Fisioterapia no pós-operatório de cirurgia cardíaca: A percepção do paciente. Revista Brasileira de Cirurgia Cardiovascular, 26, 244-249. https://doi.org/10.1590/S0102-76382011000200015

[4] Mansur, A.P. and Favarato, D. (2016) Mortalidade por doenças cardiovasculares em mulheres e homens nas cinco regiões do Brasil, 1980-2012. Arquivos Brasileiros de Cardiologia, 107, 137-146.

[5] Ferreira, L.G.F.F., Couto, A.S. and Ykeda, D.S. (2013) Efeitos da ventilação mecânica não invasiva no pós-operatório de cirurgia cardíaca: Revisão da literatura. Fisioterapia \& Saude Funcional, 2, 44-50. http://periodicos.ufc.br/fisioterapiaesaudefuncional/article/view/20571/31005

[6] Siqueira, A.S.E., Siqueira-Filho, A.G. and Land, M.G.P. (2017) Análise do impacto econômico das doenças cardiovasculares nos últimos cinco anos no Brasil. Arquivos Brasileiros de Cardiologia, 109, 139-146.

[7] Herdy, A.H., López-Jiménez, F., Terzic, C.P., Milani, M., Stein, R. and Carvalho, T. (2014) Diretriz Sul-Americana de prevenção e reabilitação cardiovascular. Arquivos Brasileiros de Cardiologia, 103, 1-31.

[8] Oliveira, S.S., Neto, M. and Aras Júnior, R. (2018) Terapia de expansão pulmonar na oxigenação arterial e nível sérico de lactato no pós-operatório de cirurgia cardíaca. International Journal of Cardiovascular Sciences, 31, 63-70.

[9] Costa, C.C., Pires, J.F. and Abdo, S.A. (2016) Protocolo de reabilitação cardiopul- 
monar em pacientes submetidos à cirurgias cardíacas em um hospital de Novo Hamburgo: Um estudo-piloto. Revista $A M R I G S$, 60, 1-6.

[10] Baranow, K.V., Silva, N.M., Moussalle, L.D. and Kessler, A. (2016) Inspirômetro de incentivo no pós-operatório de cirurgia torácica: Uma revisão sistemática. Cienc Saude, 9, 210-217. https://doi.org/10.15448/1983-652X.2016.3.23081

[11] Soares, G.M.T., Ferreira, D.C.S., Gonçalves, M.P.C., Alves, T.G.S., David, F.L., Henriques, K.M.C. and Riani, L.R. (2011) Prevalência das principais complicações pós-operatórias em cirurgia cardíaca. Revista Brasileira de Cardiologia, 4, 139-146.

[12] Steffens, E., Dallazen, F., Sartori, C., Chiapinotto, S., Battisti, I.D.E. and Winkelmann, E.R. (2016) Condições físico-funcionais e qualidade de vida de pacientes no pré e pós-operatório de cirurgia cardíaca. Revista Pesquisa em Fisioterapia, 6, 422-429. https://doi.org/10.17267/2238-2704rpf.v6i4.1149

[13] Cavalcante, E.S., Magario, R., Conforti, C.A., Cipriano Júnior, G., Arena, R. and Carvalho, A.C.C. (2014) Impacto da fisioterapia intensiva no pós-operatório de revascularização miocárdica. Arquivos Brasileiros de Cardiologia, 102, 121-127.

[14] Cavenaghi, S., Ferreira, L.L., Marino, L.H.C. and Lamari, N.M. (2011) Fisioterapia respiratória no pré e pós-operatório de cirurgia de revascularização do miocárdio. Revista Brasileira de Cirurgia Cardiovascular, 26, 455-461. https://doi.org/10.5935/1678-9741.20110022

[15] Ortiz, L.D.N., Schaan, C.W., Leguisano, C.P., Tremarin, K., Mattos, W.L.L.D. and Kalil, A.K. (2010) Incidência de complicações pulmonares na cirurgia de revascularização do miocárdio. Arquivos Brasileiros de Cardiologia, 81, 132-139. https://doi.org/10.1590/S0066-782X2010005000115

[16] Marques, A.M.R., D’Alessandro, W.B. and D’Alessandro, A.A.B. (2017) Estudo de revisão: A eficácia de protocolos de fisioterapia na prevenção das disfunções pulmonares no pós-operatório da revascularização miocárdica. Revista Amazônia: Science \& Health, 5, 48-52.

[17] Crisafulli, E., Venturelli, E. and Siscaro, G. (2013) Respiratory Muscle Training in Patients Recovering Recent Open Cardiothoracic Surgery: A Randomized-Controlled Trial. BioMed Research International, 13, Article ID: 354276. https://doi.org/10.1155/2013/354276

[18] Braun, S.R., Birnbaum, M.L. and Chopra, P.S. (1978) Pre and Postoperative Pulmonary Function Abnormalities in Coronary Artery Revascularization Surgery. Chest, 73, 316-320. https://doi.org/10.1378/chest.73.3.316

[19] Berrizbeitia, L.D., Tessler, S., Jacobowitz, I.J., Kaplan, P., Budzilowicz, L. and Cunningham, J.N. (1989) Effect of Sternotomy and Coronary Bypass Surgery on Postoperative Pulmonary Mechanics. Chest, 96, 873-876. https://doi.org/10.1378/chest.96.4.873

[20] Shapira, N., Zabatino, S.M., Ahmed, S., Murphy, D.M.F., Sullivan, D. and Lemole, G.M. (1990) Determinants of Pulmonary Function in Patients Undergoing Coronary Bypass Operations. The Annals of Thoracic Surgery, 50, 268-273. https://doi.org/10.1016/0003-4975(90)90747-T

[21] Shenkman, Z., Shir, Y., Weiss, Y.G., Bleiberg, B. and Gross, D. (1997) The Effects of Cardiac Surgery on Early and Late Pulmonary Functions. Acta Anaesthesiologica Scandinavica, 41, 1193-1199. https://doi.org/10.1111/j.1399-6576.1997.tb04865.x

[22] Westerdahl, E., Lindmark, B., Bryngelsson, I. and Tenling, A. (2003) Pulmonary Function 4 Months after Coronary Artery Bypass Graft Surgery. Respiratory Medicine, 97, 317-322. https://doi.org/10.1053/rmed.2002.1424 
[23] Van Belle, A.F., Wesseling, G.J., Penn, O.C.K.M. and Wouters, E.F.M. (1992) Postoperative Pulmonary Function Abnormalities after Coronary Artery Bypass Surgery. Respiratory Medicine, 86, 195-199. https://doi.org/10.1016/S0954-6111(06)80054-5

[24] Johnson, D., Hurst, T., Thomson, D., Mycyk, T., Burbridge, B. and To, T. (1996) Respiratory Function after Cardiac Surgery. Journal of Cardiothoracic and Vascular Anesthesia, 10, 571-577. https://doi.org/10.1016/S1053-0770(96)80130-3

[25] Rachwalik, M. (2018) Spirometric Changes after Valve Surgery. Clinical and Experimental Medical Letters, 9, 173-178.

[26] Vaidya, R., Husain, T. and Ghosh, P.K. (1996) Spirometric Changes after Open Mitral Surgery. The Journal of Cardiovascular Surgery, 37, 295-300.

[27] Baltieri, L., Santos, A., Pessoti, E. and Forti, E.M.P. (2012) Estimulação diafragmática elétrica transcutânea na paralisia diafragmática após cirurgia cardíaca. Revista Brasileira de Cardiologia, 25, 504-506.

[28] Dimopoulou, I., Daganou, M., Dafni, U., Karakatsani, A., Khoury, M. and Geroulanos S. (1998) Phrenic Nerve Disfunction after Cardiac Operations. Chest, 113, 8-14. https://doi.org/10.1378/chest.113.1.8

[29] Efthimiou, J., Butker, J., Woodham, C., Benson, M.K. and Westaby, S. (1991) Diaphragm Paralysis Following Cardiac Surgery: Role of Phrenic Nerve Cold Injury. The Annals of Thoracic Surgery, 52, 1005-1008. https://doi.org/10.1016/0003-4975(91)91268-Z

[30] Curtis, J.J., Nawarawong, W., Walls, J.T., Schmaltz, R.A., Boley, T. and Madsen, R. (1989) Elevated Hemidiaphragm after Cardiac Operations: Incidence, Prognosis, and Relationship to the Use of Topical Ice Slush. The Annals of Thoracic Surgery, 48, 764-768. https://doi.org/10.1016/0003-4975(89)90667-X

[31] Landymore, R.W. and Howell, F. (1990) Pulmonary Complications Following Myocardial Revascularization with the Internal Mammary Artery Graft. European Journal of Cardio- Thoracic Surgery, 4, 156-162. https://doi.org/10.1016/1010-7940(90)90187-5

[32] Forshag, M.S. and Cooper, A.D. (1992) Postoperative Care of the Thoracotomy Patients. Clinics in Chest Medicine, 13, 33-45. 